\title{
Gazi Üniversitesi Tıp Fakültesi Dönem 2 Öğrencilerinin Algılanan Öğrenme Düzeyleri, Uyku Kaliteleri Ve İçecek Tüketimleri Arasındaki İlişkinin İncelenmesi
}

\section{The Examination of Relation Between Perceived Learning, Sleep Quality And Drink Consumption of Gazi University Medical Faculty Second Year Students}

\author{
Yavuz Selim Klyak (ORCID: 0000-0002-5026-3234) \\ Özlem Coşkun (ORCID: 0000-0001-8800-4433) \\ Irem Budakoğlu (ORCID: 0000-0003-1517-3169) \\ Gazi Üniversitesi Tıp Fakültesi, Tıp Eğitim ve Bilişimi AD \\ Sorumlu Yazar: Yavuz Selim Kiyak \\ Bu çalışma Ulusal Tıp Eğitimi Sempozyumu 2019'da poster bildiri olarak sunulmuştur.
}

\section{Anahtar Sözcükler: tıp ögrrencileri, uyku kalitesi, algılanan öğrenme düzeyi, içecek tüketimi \\ Keywords: \\ medical students, sleep quality, perceived learning level, drink consumption}

Gönderilme Tarihi

Submitted:24.04.2019

Kabul Tarihi

Accepted: 29.07.2019
ÖZET:

Amaç: Gazi Üniversitesi Tıp Fakültesi dönem 2 öğrencilerinin algılanan öğrenme düzeyleri, uyku kaliteleri ve içecek tüketimleri arasındaki ilişkiyi incelemek.

Gereç-Yöntem: Çalışmanın evrenini Gazi Üniversitesi Tıp Fakültesi dönem 2 öğrencileri oluşturmaktadır. Çalışmanın gerçekleştirildiği 2016-2017 eğitim öğretim yılında toplam 359 dönem 2 öğrencisi vardır. Öğrencilere, sosyodemografik bilgileri ve içecek tüketimi alışkanlıklarını sorgulayan sorularla beraber Algılanan Öğrenme Ölçeği'ni ve Pittsburgh Uyku Kalitesi Ölçeği'ni (PUKÖ) içeren anket formu uygulanmıştır. Algılanan Öğrenme Ölçeği'nde daha yüksek puanlar, algılanan öğrenmenin daha iyi olduğunu gösterirken Pittsburgh Uyku Kalite Ölçeği'nden alınan puan yükseldikçe uyku kalitesi kötüleşmektedir. Verilerin istatistikî analizi SPSS v.22.0 for Windows paket programında yapılmış, anlamlılık düzeyi 0.05 olarak kabul edilmiştir.

Bulgular: Evrenin \%86.1'ine ( $\mathrm{N}=309)$ ulaşılmıştır. Değerlendirmeye dâhil edilen 306 öğrencinin \%16.3'ü ( $\mathrm{N}=50)$ sigara kullanmakta, \%71.5'i $(\mathrm{N}=218)$ her gün çay, \%32.5'i ( $=99)$ her gün kahve içmekte; \%78.8'i (N=238) alkolü, \%69.6's1 (N=211) enerji içeceklerini hiç tüketmemektedir. Öğrencilerin günlük uyku süreleri ortalama $7.24 \pm 1.31$ saattir.

Künye: Kıyak YS, Coşkun Ö. Budakoğlu İ. Gazi Üniversitesi Tıp Fakültesi Dönem 2 Öğrencilerinin Algılanan Öğrenme Düzeyleri, Uyku Kaliteleri ve Iç̧ecek Tüketimleri Arasındaki İlişkinin İncelenmesi. Tıp Eğitimi Dünyası. 2019;18(56):56-65 
Öğrencilerin PUKÖ puanı ortalaması $6.02 \pm$ 2.81 olup, \%69.3'ünün uyku kalitesinin kötü (PUKÖ puanı 5 ve üzeri) olduğu belirlenmiştir. Algılanan Öğrenme Düzeyi ile PUKÖ puanı arasında negatif yönlü anlamlı ilişki vardır ( $\mathrm{r}=-0.103, \mathrm{p}<0.05)$. Algılanan Öğrenme Düzeyi'nde, sigara içmeyenlerin ortalaması $(4.77 \pm 0.05)$, içenlerin ortalamasından (4.52 \pm 0.12 ) yüksektir ( $p=0.050)$. Enerji içecekleri tüketimi ile Algılanan Öğrenme Düzeyi arasında $(\mathrm{r}=-0.12, \mathrm{p}<0.05)$ negatif yönlü, kahve tüketimi ile PUKÖ puanı arasında $(\mathrm{r}=0.12$, $\mathrm{p}<0.05$ ) pozitif yönlü anlamlı ilişki saptanmıştır. Sonuç: Öğrencilerin uyku kalitesi kötüdür. Öğrenme becerilerini güçlendirmek için uyku kalitesini iyileştirme ve içecek tüketim alışkanlıklarını değiştirme yönünde çaba harcanması

\section{ABSTRACT:}

Aim: To examine the relation between perceived learning level, sleep quality and drink consumption of Gazi University Medical Faculty second year students.

Material-Method: There were 359 second year students in total at Gazi University Medical Faculty, when the study was conducted - in 2016-2017 academic year. The questionnaire form, which contains Perceived Learning Scale and Pittsburgh Sleep Quality Index (PSQI) as well as questions which ask on sociodemographic attributes and drink consumption habits, was performed. While getting higher scores in Perceived Learning Scale means the student have better perceived learning, getting higher scores in Pittsburgh Sleep Quality Index shows the student have worse sleep quality. Data was analyzed using SPSS v.22.0 for Windows. Significance level was accepted as 0.05.

Results: From total number of students, $86.1 \%$ $(N=309)$ of them were reached. Of the 306 students which were included the study, 16.3\% $(N=50)$ were smoker. $71.5 \%(N=218)$ of students drink tea and 32.5\% (N=99) drink coffee everyday, $78.8 \%(N=238)$ have never consumed alcohol, 69.6\% $(N=211)$ have never consumed energy drink. Mean of their sleep durations in a day is $7.24 \pm 1.31$ hours. Mean score of PSQI was $6.02 \pm 2.81$. Poor sleep quality (PSQI $\geq 5$ ) were found in $69.3 \%$. PSQI score was significantly correlated with Perceived Learning Level ( $r=-0.103, p<0.05)$. Mean of Perceived Learning Level was $4.77 \pm 0.05$ for smokers, $4.52 \pm 0.12$ for non-smokers and the difference were significant $(p=0.050)$. Energy drink consumption was significantly correlated with Perceived Learning Level ( $r=-0.12, p<$ $0.05)$ and coffee consumption was significantly correlated with PSQI score $(r=0.12, p<0.05)$.

Conclusion: Sleep quality of students is poor. In order to make students' learning skills better, it can be reasonable to seek the ways to make their sleep quality better and to change drink consumption habits of them.

\section{GíRiş}

Tıp eğitiminin doğası gereği, formal eğitim sonucunda öğrenciye "öğrenmen gerekenler bu kadardı" denilmesine izin verilememekte, öğrencininyaşamboyuöğrenmeyikendinerehber edinmesi gerekmektedir. Bu yüzden tıp eğitimi sürecinde öğrenme becerisini güçlendirmek, eğitimin önemli bir bileşenidir (1). Öğrenmenin gerçekleşebilmesi içinse öğrencinin türe özgü hazır oluş, olgunlaşma, genel uyarılmışlık hâli ve güdülenme (motivasyon) başlıklarında belirli bir düzeyde olması gerekir (2). Tıp öğrencileri yaşları ve konumları gereği türe özgü hazır oluş ve olgunlaşma bakımından genellikle en baştan yeterli olmalarına rağmen genel uyarılmışlık hâli ve güdülenme öğrenciden öğrenciye değişebilir. Hem uyarılmışlığı hem güdülenmeyi etkileyen faktörlerden ikisi uyku ve içecek tüketimi 
alışkanlıklarıdır. Uyku kalitesi düşük, içecek tüketimi alışkanlıkları dengesiz olan öğrencilerin öğrenmenin önemli bileşenlerinden güdülenme açısından eksiklik yaşaması olasıdır (2). Neden uyuduğumuz hakkında çok sayıda hipotez öne sürülmüş olsa da, uykuda bellek pekiştirme meydana geldiğine, sinaptik reorganizasyon yapıldığına dair hipotezler son dönemde ön plana çıkmaktadır (3). Gün boyu alınan veriler, uykuda düzenlenip yeni bilgi ağları hâlinde bütünleştirilir (4). Uyku kalitesindeki düşüklük bilişsel performansta azalmaya, öğrenmeye kapalı olmaya, yapılan işlerde verimin düşmesine neden olmaktadır. Bununla beraber, uyku yoksunluğu ile öğrencilerin akademik performansı arasında anlamlı ilişki olduğu gösterilmiştir (5).

Çay, kahve, alkol, kola, enerji içecekleri, süt ve süt ürünleri toplumda yaygın olarak tüketilen içeceklerdir (6-8). Uykunun yanı sıra içecek tüketimi alışkanlıklarının da öğrenme becerilerine etkisi olduğunu yukarıda belirtmiştik. Buna ek olarak, yapılan bazı çalışmalarda üniversite öğrencilerinde çay tüketimiyle uyku kalitesi arasında (9), tıp fakültesi öğrencilerinde enerji içecekleri tüketimiyle yine uyku kalitesi arasında bir ilişki olduğu saptanmıştır (10). Bu da göstermektedir ki bu içecekler dolaylı olarak, uyku kalitesi üzerinden öğrenme becerileriyle de ilişkilidir. Kahve tüketiminin hafıza ve dikkat ile (11), alkol tüketiminin de bilişsel performansla ilişkisi olduğunu gösteren kanıtlar vardır (12). Yukarıda ifade ettiğimiz bilgiler 1şığında, tıp öğrencilerinde uyku kalitesinin ve içecek tüketiminin öğrenmeyle ilişkisinin incelenmesinin önemli olduğu yönünde bir çıkarım yapılabilir. Söz konusu çıkarımdan hareketle biz bu çalışmada, Gazi Üniversitesi Tıp Fakültesi dönem 2 öğrencilerinin algılanan öğrenme düzeyleri, uyku kaliteleri ve içecek tüketimleri arasındaki ilişkiyi incelemeyi amaçladik.

\section{GEREÇ-YÖNTEM}

$\mathrm{Bu}$ çalışmanın evrenini Gazi Üniversitesi Tıp Fakültesi dönem 2 öğrencileri oluşturmaktadır. Fakültenin eğitim programında temel tıp bilimleri dersi ağırlıklı olarak dönem 2'de yer almaktadır. $\mathrm{Bu}$ nedenle araştırmanın dönem 2'lerde yapılması planlanmıştır. Araştırmanın yapıldığ 2016-2017 eğitim y1lında toplam 359 dönem 2 öğrencisi bulunmaktadır. $\mathrm{Bu}$ öğrencilerin tamamına ulaşılması hedeflenmiştir. Öğrencilere, sosyodemografik bilgilerin ve içecek tüketimi alışkanlıklarının ortaya çıkarılması için oluşturulmuş soruların yanında; Rovai ve ark. tarafindan oluşturulan (13), Albayrak ve ark. tarafindan Türkçeye uyarlanan (14) Algılanan Öğrenme Ölçeği ve University of Pittsburgh'daki araştırmacılar tarafından oluşturulan (15), Önder ve ark. tarafindan Türkçeye uyarlanan (16) Pittsburgh Uyku Kalite Ölçeği'ni (PUKÖ) içeren anket formu uygulanmıştır. Algılanan Öğrenme Ölçeği'nde daha yüksek puanlar, algılanan öğrenmenin daha iyi olduğunu gösterirken Pittsburgh Uyku Kalite Ölçeği'nden alınan puan yükseldikçe uyku kalitesi kötüleşmektedir.

Verilerin istatistikî analizinde $\mathrm{T}$ testi, Mann Whitney $U$ testi ve Spearman korelasyon analizi kullanılmıştır. Analizler SPSS v.22.0 for Windows (Chicago, IL, USA) paket programında yapılmıştır. Analizler yapılırken istatistiksel anlamlılık düzeyi 0.05 olarak kabul edilmiştir.

\section{BULGULAR}

Anket formunu $309 \quad(\% 86.1) \quad$ öğrenci doldurmuştur. $\mathrm{Bu}$ formlardan 306's1 değerlendirmeye dâhil edilmiştir. Değerlendirmeye dâhil edilen öğrencilerin 
\%50.0'si kadın ( $\mathrm{N}=153)$, \%19,9'unun ( $\mathrm{N}=61$ ) doğum yeri Ankara'dır. Öğrencilerin yaşları 19-28 arasında değişmekte olup, \%87'sinin $(\mathrm{N}=266)$ yaşı 20, 21 veya 22' dir.

Öğrencilerin $\% 16.3$ 'ü $\quad(\mathrm{N} \quad=50)$ sigara kullanmaktadır, \%2'si $(\mathrm{N}=6)$ ise bir süre kullandıktan sonra birakmıştır. Sigara kullananların tüketiminin ortalama $0.72 \pm 0.33$ paket/gün olduğu görülmüştür. Sigara kullanma süreleri ortalama $3.52 \pm 2.69$ yıldır. Öğrencilerin \%71.5'i $(\mathrm{N}=218)$ her gün çay, \%32.5'i $(\mathrm{N}=99)$ her gün kahve içmekte; \%78.8'i (N=238) alkolü, \%69.6's1 (N=211) enerji içeceklerini hiç tüketmemektedir. Grafik 1-6'da öğrencilerin içecek alışkanları hakkında bilgi sağlanmıştır.

Öğrencilerin günlük uyku süreleri ortalama 7.24 \pm 1.31 saattir. \%88.6'sı $(\mathrm{N}=271)$ hiç uyku ilacı kullanmamaktadır. Çalışmamızda PUKÖ puanı ortalaması $6.02 \pm 2.81$ olarak bulunmuştur. Öğrencilerin \%69.3’ünün uyku kalitesinin kötü (PUKÖ puan1 5 ve üzeri) olduğu belirlenmiştir. Algılanan Öğrenme Düzeyi ile PUKÖ puanı arasında negatif yönlü anlamlı ilişki saptanmıştır ancak bu ilişki çok zayıftır $(r=-0.103, p<0.05)$. Sigara içenlerle içmeyenler arasında Algılanan Öğrenme Düzeyi ve Uyku Kalitesi farklılığı da incelenmiştir. Algılanan Öğrenme Düzeyi'nde, sigara içmeyenlerin ortalaması $(4.77 \pm 0.05)$, içenlerin ortalamasından $(4.52 \pm 0.12)$ yüksektir $(p=0.050)$. Uyku Kalitesi ile sigara içme arasında ise istatistiksel açıdan anlamlı bir ilişki saptanmamıştır ( $\mathrm{p}>0.05)$.

İçecek tüketiminin Algılanan Öğrenme Düzeyi ve Uyku Kalitesi ile ilişkisini incelemek için yapılan analizde; kolalı içeceklerin tüketimi ile Algılanan Öğrenme Düzeyi arasında ( $\mathrm{r}=$ -0.15, p <0.05) ve enerji içecekleri tüketimi ile Algılanan Öğrenme Düzeyi arasında $(r=-0.12$, $\mathrm{p}<0.05)$ negatif yönlü, kahve tüketimi ile PUKÖ puanı arasında $(r=0.12, \mathrm{p}<0.05)$ pozitif yönlü anlamlı ilişki saptanmıştır.
Diğer içecek tüketimleri ("çay", "alkol”, "süt, ayran gibi içecekler”) ile Algılanan Öğrenme Düzeyi ve/veya Uyku Kalitesi arasında, kolalı içeceklerin ve enerji içeceklerin tüketimi ile Uyku Kalitesi arasında, kahve tüketimi ile Algılanan Öğrenme Düzeyi arasında anlamlı ilişki bulunamamıştır ( $\mathrm{p}>0.05)$.

\section{TARTIŞMA}

Çalışmamızdaki bulgular, öğrencilerin PUKÖ puanı ortalamasının $6.02 \pm 2.81$ olduğuna işaret etmekte ve bunun gerek Türkiye'de gerek yurtdışında tıp fakültesi öğrencileri ile yapılan çalışmalarla uyumlu olduğu görülmektedir. Yapılan çalışmalarda PUKÖ puanı ortalamaları Düzce'de $5.2 \pm 2.7$ (17), Sakarya'da $5.7 \pm$ 2.3 (18), İran'da $5.38 \pm 2.31$ (19), Fas'ta 6.3 \pm 3.0 (20), Amerika Birleşik Devletleri'nde (ABD) $6.37 \pm 2.57$ (21), Litvanya'da 6.56 (22), Suudi Arabistan'da $7.11 \pm 3.84$ (23) olarak bulunmuştur.

Çalışmamızda uyku kalitesi kötü olan öğrencilerin oranı \%69.3'tü. Yine tıp fakültesi öğrencileri ile yapılan çalışmalarda bu oran Düzce'de \%46.4 (17), Sakarya'da \%64,2 (18), ABD'de \%50.9 (21), \%Fas'ta \%58.2 (20), Zambiya'da \%59.6 (24), İran'da \%61.7 (19), Kolombiya'da \%65.7 (25), Suudi Arabistan'da \%76 (23) olmuştur. Burada dikkat edilmesi gereken nokta, "kötü uyku kalitesi"nde sınır (cut-off) değerinin kaç olarak kabul edildiğidir. Biz, tıpkı Sakarya'da yapılan çalışmanın da temel aldığı gibi Türk Toraks Derneği Obstrüktif Uyku Apne Sendromu Tanı ve Tedavi Uzlaşı Raporu'ndaki (26) sınır değeri temel aldığımız için PUKÖ puanı 5 ve üzeri olan öğrencileri "kötü uyku kalitesine sahip" şeklinde değerlendirdik. Oysa Düzce'de yapılan çalışmada ölçüt "5 puanın üzerinde olmak" şeklinde alınmıştır (17). Dolayısıyla Düzce' deki oranın bizim çalışmamızdakinden düşük 
olmasının bundan kaynaklandığı düşünülebilir. Çalışmamızda Algılanan Öğrenme Düzeyi ile Uyku Kalitesi arasında zayıf da olsa negatif yönlü anlamlı bir ilişki bulunduğu görülmektedir. Literatürde tıp fakültesi öğrencilerinde direkt bu iki unsur arasındaki ilişkiyi inceleyen çalışmaya rastlamamış olsak da Sakarya'da yapılan çalışmada uyku kalitesi ile ders notu arasında negatif yönlü zayıf bir ilişki (18), Fas’ta yapılan çalışmada ise kötü uyku kalitesi ile akademik performansın kötü olması arasında ilişki (20) olduğu saptanması bulgularımızı dolaylı olarak desteklemektedir. Uyku kalitesi ile ilgili bütün bu bulgular, öğrencilerin öğrenme becerisini güçlendirmek için odaklanılması gereken önemli bir noktanın uyku kalitesi olabileceğini işaret etmektedir.

Öğrencilerin \%16.3'ünün sigara kullandığ belirlenmiştir. Tıp fakültesi öğrencileri ile yapılan diğer çalışmalarda bu oran Düzce'de yapılan iki ayrı çalışmanın birinde \%14.3 (17) diğerinde \%19,7 (27), Aydın'da \%18.4 (28), İzmir'de \%19.1 (29), Isparta'da \%21 (30) olarak bulunmuştur. Çalışmamızda sigara kullanımı ile uyku kalitesi arasında anlamlı bir ilişki saptanmamıştır ancak ABD'de yapılan çalışmada tütün kullanımı ve PUKÖ puanı arasında anlamlı bir ilişki olduğu raporlanmıştır (21). Bunun aksine, tıpkı bizim çalışmamızda olduğu gibi Kolombiya'da yapılan çalışmada da kötü uyku kalitesi ile tütün tüketimi arasında anlamlı bir ilişki bulunamamıştır (25).

Çalışmamızda kötü uyku kalitesi ile kahve tüketimi arasında anlamlı ilişki saptamıştık. ABD'de yapılmış olan bir başka çalışma (10), bu bulguyu desteklemektedir. Çalışmada, her gün birer bardak kahve içme ile kötü uyku kalitesi arasında ilişki olduğu ifade edilmiştir. Bir çalışmada (24) enerji içeceği tüketimi ile kötü uyku kalitesi arasında anlamlı ilişki bulunmuş olsa da bizim çalışmamızda anlamlı bir ilişki tespit edilememiş̧ir. Uyku kalitesi ve enerji içecekleri tüketimi arasında anlamlı ilişki olup olmadığına dair farklı bulgulara ulaşılması, konuyu netleştirmek için tıp fakültesi öğrencilerinde bu ilişkinin çalışmalar yapılarak incelenmesini gerektirmektedir. Aynı durum, yukarıda bahsettiğimiz tütün kullanımı ve uyku kalitesi arasındaki ilişki için de geçerlidir.

\section{SONUÇ}

Öğrencilerin uyku kalitesi kötüdür. Uyku kalitesi ile algılanan öğrenme düzeyi arasında istatistikî olarak zayıf da olsa var olan ilişki, öğrencilerin öğrenme becerilerini güçlendirmek için uyku kalitesini iyileştirme yoluyla çözümler bulunabileceğini düşündürmektedir. Bu çözümlere katkı sunacak bir bileşen, kahve tüketimi ile uyku kalitesi arasında yine zayıf da olsa var olduğu tespit edilen ilişkiden yola çıkılarak oluşturulabilir. Ayrıca sigara, kolalı içecekler ve enerji içecekleri tüketiminin öğrenme düzeyiyle negatif yönlü ilişkisi de, öğrenme düzeyinin artırılması için eğitim programlarında ilişkili konulara yer verme, farkındalık oluşturma gibi seçenekler üzerinden yola çıkılabileceğini göstermektedir.

\section{KAYNAKLAR}

1. Whittle SR, Murdoch-Eaton DG. Studentselected projects: can they enhance lifelong learning skills?.MedicalTeacher.2002;24(1):4144. doi:10.1080/00034980120103469

2. Seven M, Engin A. Öğrenmeyi Etkileyen Faktörler. Atatürk Üniversitesi Sosyal Bilimler Enstitüsü Dergisi. 2010;12(2):189-212.

3. Öztürk L. Yanıtını arayan eski bir soru: Niçin uyuruz?. İstanbul Tip Fakültesi Dergisi. 2007;70:114-121. 
4. Diekelmann S, Wilhelm I, Born J. The whats and whens of sleep-dependent memory consolidation. Sleep Medicine Reviews. 2009;13(5):309-321. doi:10.1016/j. smrv.2008.08.002

\section{Abdulghani HM, Alrowais NA, Bin-Saad NS,} Al-Subaie NM, Haji AMA, Alhaqwi AI. Sleep disorder among medical students: Relationship to their academic performance. Medical Teacher. 2012;34(sup1):37-41. doi:10.3109/01 42159x.2012.656749

6. Çınar G, Keskin B. Bulanık Eşli Karşılaştırma Yöntemiyle Gençlerin Alkolsüz İçecek Tüketim Tercihlerinin Belirlemesi. SDÜ Ziraat Fakültesi Dergisi. 2018;13(1):9-16.

7. Babayiğit MA, Oğur R, Tekbaş ÖF, Hasde M. Genç erişkin erkeklerde alkolsüz içecek tüketim alışkanlıklarının ve etki eden faktörlerin araştırılması. Genel Tıp Dergisi. 2006;16(4):161-168.

8. Süngü H. Üniversite Öğrencilerinin Zararlı Madde Kullanımına İlişkin Tutumları/The Attitudes of University Students on Substance Use. Mustafa Kemal Üniversitesi Sosyal Bilimler Enstitüsü Dergisi. 2014;11(26):167194.

9. Tseng HC, Wang CJ, Cheng SH, Sun ZJ, Chen PS, Lee CT et al. Tea-drinking habit among new university students: Associated factors. The Kaohsiung Journal of Medical Sciences. 2014;30(2):98-103. doi:10.1016/j. kjms.2013.08.004

10. Sawah MA, Ruffin N, Rimawi M, Concerto C, Aguglia E, Chusid E et al. Perceived Stress and Coffee and Energy Drink Consumption Predict Poor Sleep Quality in Podiatric Medical Students. Journal of the American Podiatric Medical Association. 2015;105(5):429-434. doi:10.7547/14-082
11. Haskell-Ramsay C, Jackson P, Forster J, Dodd F, Bowerbank S, Kennedy D. The Acute Effects of Caffeinated Black Coffee on Cognition and Mood in Healthy Young and Older Adults. Nutrients. 2018;10(10):1386. doi:10.3390/nu10101386

12. Gutwinski S, Schreiter S, Priller J, Henssler J, Wiers C, Heinz A. Drink and Think: Impact of Alcohol on Cognitive Functions and Dementia - Evidence of Dose-Related Effects. Pharmacopsychiatry. 2018;51(4):136-143. doi: 10.1055/s-0043-118664

13. Rovai AP, Wighting MJ, Baker JD, Grooms LD. Development of an instrument to measure perceived cognitive, affective, and psychomotor learning in traditional and virtual higher education classroom settings. Internet and Higher Education. 2019;121(1):7-13.

14. Albayrak E, Güngören Ö, Horzum M. Algılanan Öğrenme Ölçeğinin Türkçeye Uyarlamas1. Ondokuz May1s Üniversitesi Eğitim Fakültesi Dergisi. 2014;33(1):1-14.

15. Buysse DJ, Reynolds CF, Monk TH, Berman SR, Kupfer DJ. The Pittsburgh Sleep Quality Index: a new instrument for psychiatric practice and research. Psychiatry Research. 1989;28(2):193-213.

16. Önder İ, Masal E, Demirhan E, Horzum MB, Beşoluk Ş. Psychometric properties of sleep quality scale and sleep variables questionnaire in Turkish student sample. International Journal of Psychological Studies. 2016;3(3):9-21.

17. Mayda AS, Kasap H, Yıldırım C, Y1lmaz M, Derdiyok Ç, Ertan D et al. 4-5-6. Sinıf Tip Fakültesi Öğrencilerinde Uyku Bozukluğu Sıklığı. Düzce Üniversitesi Sağlık Bilimleri Enstitüsü Dergisi. 2012;2(2):8-11. 
18. Erdoğan N, Karabel M, Tok Ş, Güzel D, Ekerbiçer H. Sakarya Üniversitesi Tıp Fakültesi Öğrencilerinde Uyku Kalitesi ve Etkileyen Faktörlerin Belirlenmesi. Sakarya Tip Dergisi. 2018;8(2),395-403. DOI: 10.31832/smj.413752

19. Mohammadbeigi A, Absari R, Valizadeh F, Saadati M, Sharifimoghadam S, Ahmadi A et al. Sleep Quality in Medical Students; the Impact of Over-Use of Mobile Cell-Phone and Social Networks. Journal of Research in Health Sciences. 2016;16(1):46-50.

20. El Hangouche AJ, Jniene A, Aboudrar S, Errguig L, Rkain H, Cherti M. Relationship between poor quality sleep, excessive daytime sleepiness and low academic performance in medical students. Advances in Medical Education and Practice. 2018;9:631-638. doi:10.2147/amep.s162350

21. Brick CA, Seely DL, Palermo TM. Association Between Sleep Hygiene and Sleep Quality in Medical Students. Behavioral Sleep Medicine. 2010;8(2):113-121. doi:10.1080/15402001003622925

\section{Preišegolavičiūtė E, Leskauskas D,} Adomaitienè V. Associations of quality of sleep with lifestyle factors and profile of studies among Lithuanian students. Medicina. 2010;46(7):482. doi:10.3390/medicina46070070

23. Almojali AI, Almalki SA, Alothman AS, Masuadi EM, Alaqeel MK. The prevalence and association of stress with sleep quality among medical students. Journal of Epidemiology and Global Health. 2017;7(3):169-174. doi:10.1016/j.jegh.2017.04.005

24. Mwape RK, Mulenga D. Consumption of Energy Drinks and Their Effects on Sleep Quality among Students at the Copperbelt University School of Medicine in Zambia. Sleep Disorders. 2019:1-7. doi:10.1155/2019/3434507
25. Barahona-Correa JE, Aristizabal-Mayor JD, Lasalvia P, Ruiz ÁJ, Hidalgo-Martínez P. Sleep disturbances, academic performance, depressive symptoms and substance use among medical students in Bogota, Colombia. Sleep Science. 2018;11(4):260-268. doi:10.5935/19840063.20180041

26. Türk Toraks Derneği. Obstrüktif Uyku Apne Sendromu Tanı ve Tedavi Uzlaşı Raporu. Türk Toraks Dergisi. 2012;13:59-63.

27. Sönmez C, Ayhan Başer D, Aydoğan S, Uludağ G, Dinçer D, Topaluğurlu B. Evaluation of Knowledge, Attitudes, Behaviors and Frequency of Smoking among Medical Students of Düzce University. Konuralp Medical Journal. 2017;9(2):160-166. DOI: 10.18521/ktd.331480

28. Arslan Y, Pirinççi S, Okyay P, Döger F. Tobacco Use and Related Factors Among Adnan Menderes University Faculty of Medicine Freshers. Meandros Medical And Dental Journal. 2016;17(3):146-152.

29. Açıkgöz A, Akgün M, Korkut B, Çeçen E, Kocaoğlu N, Dayı A. T1p fakültesi öğrencilerinin sağlıklı yaşam biçimi davranışları ve ilişkili etmenler: gözlemsel araştırma. Dokuz Eylül Üniversitesi Tıp Fakültesi Dergisi. 2018;32(2):99-110. DOI: 10.5505/ deutfd.2018.55477

30. Aksoy F, Kaya K, Kızılkaya Z, Çot S, Batu H, Hasoğlu İ, Bıcak G. Bir Tıp Fakültesi 3. Sınıf Öğrencilerinin Sigara İle İlgili Bilgi Ve Görüş Durumları. SDÜ Tıp Fakültesi Dergisi. 2019;26(1):90-95. DOI: 10.17343/ sdutfd.516785 
Grafik 1: Öğrencilerin çay tūketimlerinin yüzdelik dağıılım grafiği.

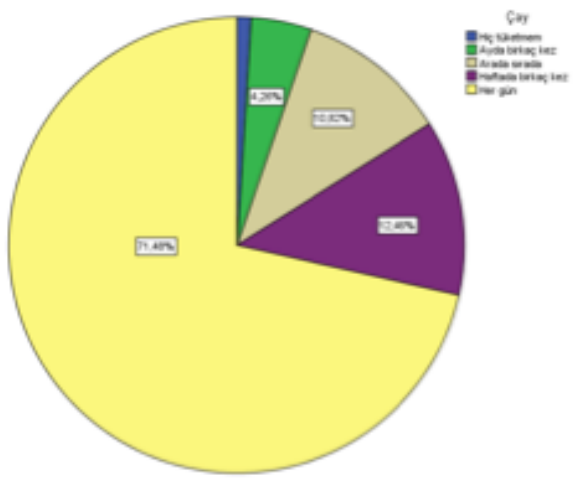

Grafik 2: Öğrencilerin kahve tūketimlerinin yüzdelik dağılım grafiği.

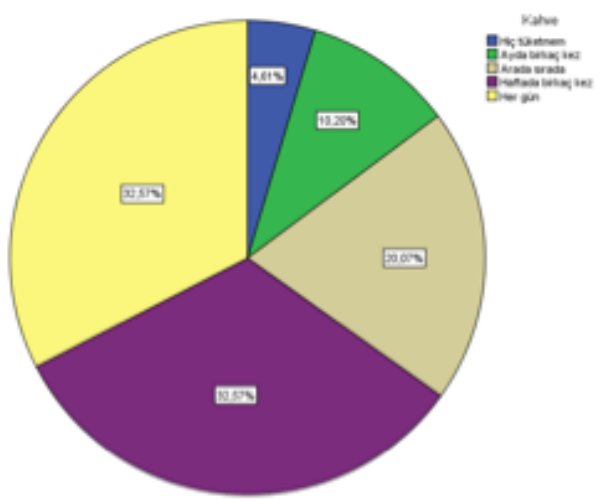


Grafik 3: Öğrencilerin alkol tüketimlerinin yüzdelik dağılım grafiği.

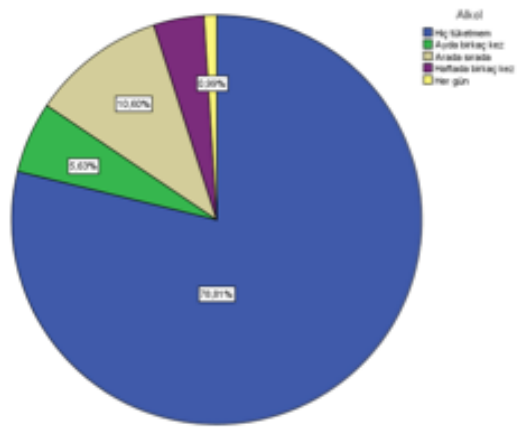

Grafik 4: Öğrencilerin kolalı içecekler tūketimlerinin yüzdelik dağılım grafiği.

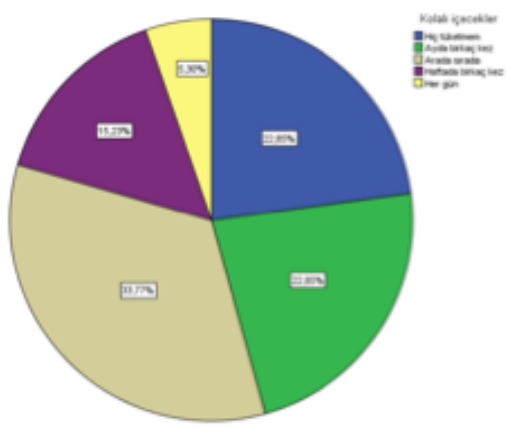


Grafik 5: Öğrencilerin enerji içecekleri tüketimlerinin yūzdelik dağılım grafiği.

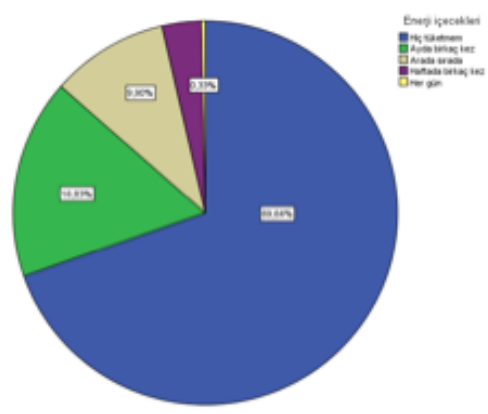

Grafik 6: Öğrencilerin süt, ayran gibi içecek tüketimlerinin yūzdelik dağılım grafiği.

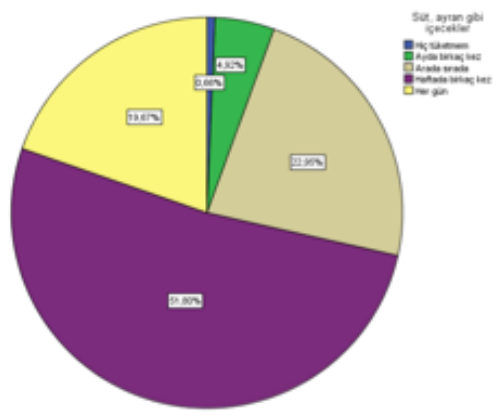

